\title{
Dehumanizacija „na kraju svijeta”
}

\section{Mãe, Valter Hugo. Dehumanizacija. Prevela Tanja Tarbuk, Vuković\&Runjić, 2016., str. 201.}

Među fjordove i gejzire, vrletne stijene i zastrašujuće ponore, smještena je priča sestara blizanki, Halldore i Sigridur, i njihove obitelji. Priča počinje opisom pokopa Sigridur i tugom ispunjenih dana preživjele sestre. Valter Hugo Mãe vrlo nam živo i slikovito pripovijeda o nestabilnoj majci, koja za smrt kćeri krivi drugu kćer te je konstantnim ranjavanjem namjerno kažnjava, nanoseći joj bol. To je i priča o odnosu oca i kćeri, koji dane provode čitajući poeziju te u njoj pronalaze sve važne odgovore, snagu i smisao života.

Došli su mi reći da će je posaditi. Da će se ponovo roditi, poput sjemenke bačene na onaj dobro čuvani komad zemlje. (9)

Znakovit je to početak romana, kojim Halla opisuje trenutak sestrine smrti, ujedno označen i kao novi početak života. Nakon njezine smrti, preživjela blizanka suočava se s vlastitim unutarnjim borbama, kao i s okolinom i neprihvaćanjem obitelji. Loš odnos s majkom kompenzira nježnim trenucima s ocem, a kasnije i kroz ljubavni odnos s Einarom, prožetim dubokim osjećajima. Einar, osebujni samotnjak kojeg su se sestre kao djevojčice plašile, za sobom vuče tajnovitu priču iz djetinjstva, kada je svjedočio ubojstvu vlastita oca, ne mogavši se kasnije sjetiti ubojičina lika.

U trudnoći, a potom i nakon gubitka djeteta, Halla trpi još silovitije ispade grubosti vlastite majke.

Rekla sam da nisam zatrudnjela iz obijesti. Nisam optužila Einara. Šutjela sam. Rekla sam da mi je narastao trbuh i da mi dolaze bolovi kao da se djeca pojavljuju unutar kostiju. Osjećala sam da ću se raspasti, raspoloviti. Moja majka, bijesna, proklinjući sve, okrivljujući me zbog grijeha razbludnosti, optuživala me da nisam dovoljno čista za prekrasno breme duše moje sestre. (79) 
Nakon tog tužnog događaja par započinje novi život. U crkvi ih udomljava Steindor. Početak je to drugog dijela romana, u kojem se pojavljuje i odmetnuta Hallina teta.

Stigla je moja teta. Spavala je na Sigridurinu mjestu i hrkala poput muškarca, dok joj je noga drhturila od noćnih mora. Došla je čak iz Höfna, s drugog kraja Islanda. (114)

Kako se ova bajkovita i neobična priča malo po malo primiče kraju, Halla i Einar raspliću klupko tajnovitog nestanka Einarova oca i otkrivaju krivce za njegovu smrt.

Halla u plamenu ostavlja svoj novi dom, imajući na umu osvetu. Tim činom okreće leđa prošlosti, koračajući prema novom životu, rasterećena bremena nemilih događaja, a vođena čistim osjećajem ljubavi.

Kroz koncept ovog književnog teksta provlače se tri strukturalna aspekta. Prvi je istaknut već u samom naslovu - proces dehumanizacije - kao logičan slijed čovjekova postojanja. Ukazivanje je to na telurički pristup životu i postojanju, odavanje počasti Prirodi i svemu što ona daje i što jest. Roman obiluje prikazima snažnih slika uzrokovanih i potaknutih djelovanjem Prirode, njezine moći i dominacije, načinom na koji sve stvara, ali i razara. Povratak Prirodi u obliku rastvaranja i truljenja važan je trenutak shvaćanja i prihvaćanja teluričke slike ljudskog života.

Takvu perspektiva omogućuje autoru karakteriziranje likove na granici realiteta. Oni se rađaju iz bajkovite zemlje Islanda, zemlje pune suprotnosti - surove i grube, ali istovremeno i lijepe.

Otac je preporučivao: Ljubi Myvatna jer ga ne razumijemo, ali on zna što radi. Ljubi Vatnajökulla jer ga ne razumiješ, ali on zna što radi. Uvijek Ijubi božja usta. (19)

Ispreplitanje stvarnog i nestvarnog, brisanje granica između dva svijeta - zemaljskog i onostranog - rastvaranje likova do njihove srži te njihovo udaljavanje od ljudskog oblika, pretvarajući ih u tlo, zrak, prirodu samu, osnovne su ideje ove osebujne pripovijetke s Islanda.

Element fantastike drugi je važan faktor u kreaciji romana. Sinestetičkim pristupom upijanja pojava oko sebe likovi kao da neprekidno nastoje izaći iz vlastitih okvira ovozemaljske ljudskosti, uranjajući hrabro u nadnaravni svijet Prirode. 
Zavukla sam mali prst među travke. Zamišljala da se moja sestra proteže kako bi me dodirnula. Mene, preplašenu pokajnicu. Kad bi me vještičjom magijom sestra sada dotaknula, značilo bi da nije bilo uzalud. Svi su potezi opravdani, ako mi potvrdi da zna za mene. (66)

Einar je legao pored mene. Tri puta me pitao što to gledam. Rekla sam: oblake. Rekao je da oni, ponekad, govore. Imaju lica i govore. (69)

Hallina životna svakodnevica rezultat je metonimijskog koncepta - njezin je život refleksija, samo dio cjeline koju tvori u neuništivoj zajednici s pokojnom sestrom. Upravo je „smrt” treći strukturalni aspekt, iznimno važan za koncept romana.

Halla iSigridur - život i smrt - dijelovi su jedinstvene cjeline, dva lica, zrcalnog sjaja jednog, jedinstvenog bića. Bića koje i dalje živi životom „manje mrtve” blizanke, kao nastavak pokopanog, tj. „Prirodi vraćenog” života sestre Sigridur, koji i dalje tinja u Hallinom životu i sjećanju.

A ja, tako blizanka i tako zrcalna, tako pronicljiva od sve te mušičavosti, nikada nisam shvatila da je imala pravo. Možda će naći smisao života u dokazu moje ljubavi. (30)

Životne potrage i nadu u pronalazak odgovora na važna pitanja o smrti kao o nastavku života, tj. njegova zemaljskog početka i smislu ljudskog postojanja uopće, autor pronalazi u osamljenoj zajednici, ambijentu dalekog, pomalo divljeg i neukroćenog Islanda, u kojem vladaju zakoni legendi i moćnih sila.

„Valterianski” stil pisanja i u ovom romanu ostaje potpuno prepoznatljiv. Autorova prepoznatljiva poetika lirizma u ovom je romanu dosegla vrhunac, ne ostavljajući mnogo prostora da se savršeno postignuto stapanje čovjeka i Prirode u budućnosti još nenapisanih djela nadmaši.

Izvrsnošću svog osebujnog književnog izraza Valter Hugo Mãe čitatelja magično uvlači u kreaciju Života i utjecaja na boljitak svijeta, time što održava budnim sva njegova osjetila i omogućuje mu njihovo ispreplitanje i potpuni angažman. U magičnom okruženju nadmoćnih božanstava, pod budnom paskom majke Prirode, protagonisti pronalaze idealne uvjete za stapanje s njom is njezinim zakonitostima, a čitatelj bespogovorno prihvaća takvu poetiku, vjerujući da je pokazani put jedini ispravan u potrazi za odgovorima i objašnjenjima vlastitog postojanja i opstanka svijeta. 
lako ovo nije jedini na hrvatski preveden roman Valtera Huga Mãea, upravo je Dehumanizacija od velike važnosti za hrvatsku književnu scenu. Ovaj je roman sublimacija autorova dosadašnjeg rada, vjerno oslikanog fantastičnog svijeta, prikazanog kroz živote sestara u zabačenom kutku zemlje. Kutku toliko drugačijem od ostatka svijeta na koji smo navikli, a koji nudi nevjerojatna rješenja i neobičan pogled na sveprisutne pojave i svakodnevne probleme. Upravo je stoga prijevod iznimno važan, jer je njegova zadaća ovdje posebno teška - prenijeti čitatelju neobičan izvorni narativ, tipično „valterianske” poetike, te ga probuditi i pomoći mu vještim sinestetičkim pristupom da uroni i lakše prihvati ovu dojmljivu životnu priču.

\section{c) (i) $(9$}

Creative Commons Attribution-NonCommercial-NoDerivatives 4.0 International License 